\title{
Ghana's foreign policy: Some regional and national interests
}

\author{
Ahmed Hajj Sanusi ${ }^{1}$ \\ Samuel Adu-Gyamfi ${ }^{2}$
}

\begin{abstract}
Dr. Kwame Nkrumah`s Non-Aligned policy has been a key variable in Ghana`s foreign policy, and successive regimes after Nhrumah have pursued this policy in various ways. Since its political reforms in 1992, Ghana has established itself as an anchor in political dispensation on the African continent. In the sub-region, Ghana is seen by other countries as a leader by exhibiting its competencies and maturity in political change and good governance, and its peacekeeping involvement in the subfield. Whiles Ghana takes credit for these attributes; her response to regional issues has not always been as readily forthcoming as in others. This paper seeks to analyze Ghana`s foreign policy directions in the sub-Saharan region, and ECOWAS. How consistent or inconsistent has Ghana been, in the implementation of foreign policy objectives within the ECOWAS, between the periods of 1992-2016? The paper leads the hypothesis that, lack of a welldefined and articulated defence policy document has somewhat resulted in inconsistencies in responding to crises in the region.
\end{abstract}

Keywords: ECOWAS; Foreign Policy; Ghana; Peacekeeping; ECOWAS Protocol.

\section{Introduction}

The difficulty of some countries to unilaterally act in responding to external issues such as security, economic diplomacy and international cooperation, has somewhat led to the formation of various organizations in the world. These organizations play a significant political role and devote attention on socio-economic and other developmental activities. Hence, the countries in West Africa have come under one economic bloc -Economic Community of West African States (ECOWAS), to maximize their potentials and facilitate the realization of the benefits of economies of scale ${ }^{3}$ [Evans, 2007].

Ghana's regional integration agenda began in the 1950s. Followed by the treaty of Lagos in 1975, which was established for it member states, to achieve a large trading avenue through an economic and trading union, and also to serve as a peacekeeping force in the region. ${ }^{4}$ Conflicts in the region have largely been triggered by post election results and coups. The many peacekeeping operations Ghana has been involved include Congo in 1960, and the Liberian and Sierra Leonean crises in the early 1990s. From the first President, Dr Kwame Nkrumah, Ghana has inherited part of its current foreign policy of Pan-Africanism. Geographical location could also be the reason for

\footnotetext{
1 Ph.D. candidate, People`s Friendship University of Russia, Department of Theory and History of International Relations, hajjsanusi@yahoo.com

${ }^{2}$ Lecturer, Kwame Nkrumah University of Science and Technology, Department of History \& Political Studies, mcgyamfi@yahoo.com

${ }^{3}$ Evans S.c. Osabuohien "Trade Openness and Economic Performance of ECOWAS Members- Reflections From Ghana And Nigeria”. African Journal of Business and Economic Research (AJBER) Vol.2 Nos. 2\&3, pp57-73. (Covenant University Ota, Nigeria 2007)

${ }^{4}$ Formation of ECOWAS treaty: Agreement signed by member states. Lagos 1975.
} 
Sanusi, H., \& Adu-Gyamfi, S. (2017). Ghana's foreign policy: Some regional and national interests. Journal of Human Sciences, 14(1), 598-608. doi:10.14687/jhs.v14i1.4370

its involvement in regional affairs. Ghana is located along the Gulf of Guinea and Atlantic Ocean, in the sub region of West Africa. Regional activities and African affairs in general, have always been a priority of Ghana's Foreign Policy ${ }^{5}$ [Afua, 2009]. Hence its membership and support for the OAU (now AU) and ECOWAS.

Dr. Nkrumah`s Pan-African ideology whose vision was to have a United States of Africa continues to be part of Ghana`s foreign policy agenda, as far as West Africa and the rest of Africa are concern. ${ }^{6}$ This has become a key element of development since it foster cooperation among Africans through regional integration such as ECOWAS. Series of developmental strategies in the early days of independence led to many initiatives devoted to liberating the continent did not yield much success. Felipe Herrera (1963) argues that, "economic integration is a response to political challenge, a political response that is also a political process" "[Herrera, 1963]. The success of integration is essential for Africa. This explains why regional organization such as ECOWAS, is a key developmental avenue for member states.

Professor, F. S. Northedge (1918-1985), defined Foreign Policy as "the use of political influence in order to induce other states to exercise their law-making power in a manner desired by the states concerned: it is an interaction between forces originating outside the country's borders and those working within them". ${ }^{8}$ Willace (1991), states it as "the general orientation of one government towards other governments: building alliances and coalitions in pursuit of defined national interest and preferred models of international order"'. Webber \& Smith (2002), also defined foreign policy as "the goals sought, values set, decisions made and actions taken by states, and national governments acting on their behalf, in the context of external relations of national societies. It constitutes an attempt to design, manage and control the foreign relations of national societies" $"$ [Webber \& Smith, 2002]. Per these definitions, we can define Foreign Policy as a country`s policy on dealing with international issues and how it reacts to external events. These decisions are sometimes influenced by history, security, trade, political circumstances at a time, leadership status and national interest.

Ghana`s external policy objectives includes - opposition to any military alliance, apartheid, arm race, establishment of foreign military bases on the territories of member states, the strengthening of the United Nations, the democratization of international relations, socioeconomic development and the restructuring of the international economic system, as well as international cooperation on an equal footing. The above mentioned hence defines the policy and ideology of Non-Aligned Movement $(\mathrm{NAM})^{11}$ [Bluwey, 2003]. This policy is one of the variables which influence Ghana`s foreign policy, and since the days of Dr. Nkrumah, different regimes have pursued the policy of non aligned in various ways. Ghana`s external priorities thus include maintaining good relations and co-operations with any country that may be interested in that cooperations and ideologies.

Against this background, has Ghana always played a positive role in West African affairs? To what extent does Ghana`s founding ideologies of African unity and non aligned, manifest into regional affairs? How consistent or inconsistent has Ghana been, in the implementation of foreign policy objectives within the ECOWAS, between the periods of 1992-2016? These questions are important because, on the one hand, Ghana`s political reforms have reinforced the "role model"

\footnotetext{
5 Afua Boatemaa Yakohene "Overview of Ghana and Regional Intergration: Past, Present and Future (FriendrichEbert-Stiftung, Ghana, 2009)

${ }^{6}$ Kwame,Boafo-Arthur, "Trends in Ghanae s Foreign Policy after Nkrumah" in Hansen, E. and Ninsin, K. A. (eds.)

7 Herrera Felipe (1963), "Economic Integration and Political Re-integration", in M Adams (ed.) Latin America: Evolution or Explosion, (New York: Doad Meed and Co). pp. 94-95.

${ }^{8}$ F. S. Northedge was a British Professor of International Relations at the London School of Economics.

9 William Willace, "Foreign Policy and National Identity in the United Kingdom" (Royal Institute of International Affairs, January 1991) Vol. 64, No 1. pp. 65-80

${ }^{10}$ Mark Webber \& Michael Smith "Foreign Policy in a Transformed World” (Loughborough University, 2002)

${ }^{11}$ G.R., Bluwey, Understanding International Relations, (Accra: Yamens Press Limited, 2003) pp44-45.
} 
status and somewhat established its image as a leader for political change on the African continent. On the other hand, several questions arise concerning Ghana's role in managing the West African affairs. In March 1993, Togolese government accused Ghana for supporting an armed attack on the military camp at Lome, which led to the killing of 12 Ghanaians, and the arrest of Ghanaian charge d'affairs (diplomat) in Togo ${ }^{12}$ McCakie, 2004]. Regional issues such as the Togo crisis in 2005, Niger in 1999, and the Cote d'Ivoire crises in 2010-2011, were met with cautious silent from Ghanaian government. In addition to aiding in research on Ghana`s regional policy, this paper aims at adding to the many already written scientific research. Researchers such as, Evans (2007), Rodrigo (2011), Herbert (1996), and others have all touched on similar topic. While such efforts by recognized groups and entities have, in some cases, yielded positive results, there is still much work to be done to ensure that the grey areas in the literature concerning Ghana's contribution to the peace and security and economic enhancement of West Africa.

Although, the earlier works that is related to this paper were largely accepted, this paper seeks to analyze Ghana`s foreign policy direction in the West African region and how that ties into her contributions towards the attainment of the objectives and principles upon which ECOWAS policies are based.

The above objective would be achieved by focusing attention on Ghana's peace and security activities and how that ties into ECOWAS protocol which allows free movement of people, goods and services within the member states.

The above notwithstanding, the selection of this theme is based on the understanding that, little scientific work has been done on the subtopic. Similarly, Birikorang (2007), contends that, "the absence of a well-defined and articulated defense policy document has sometimes resulted to Ghana 's negative response to crisis such as in Togo and Cote d'Ivoire". This paper will further look into the wider ramifications of the potential threats that these pose to the state and its citizens.

\section{Basis for Ghana`s regional involvement:}

Historically, Ghana's sub-regional policy or relations with countries like Togo, Burkina Faso, Ivory Coast and Nigeria from the period between 1957-1981 has been an interesting case in point. Writing in 1992, Chazan argued that bordered in the south, north, east and west by the Gulf of Guinea, Burkina Faso, Togo and, Cote d'lvoire respectively, the political history of Ghana has "embraced the most salient themes of the (post-colonial) African experience: instability, ideological experimentation.., and fundamental issues of governance [Chazan 1992: 300].

Successive governments after Nkrumah did follow some part of Non-Aligned policy which fosters cooperation among Africans through regional integration such as ECOWAS ${ }^{13}$ [Debrah, 2002]. The 1992 constitution of Ghana could also be the reason for its commitment to international organizations. Part of Ghana's constitution pays attention to treaty obligations and settlement of international disputes by peaceful means, and "adhere to the principles enshrined in or as the case may be, the aims and ideals of the UN Charter, the OAU Charter, the Commonwealth, the ECOWAS Treaty and any other organization of which Ghana is a member."14 Membership of these organizations provide Ghana with a platform for protecting some of its interests, as well as to establish itself as a leader on several issues of concern to the African continent. Through the UN and ECOWAS for example, Ghana has been able to engage in numerous peacekeeping missions, which earns it international respect as a partner for global stability and a moral leader in African affairs. It is important to state that, while peacekeeping activities come with its own cost (human lives and casualties), Ghana's involvement in international

\footnotetext{
12 T.C.McCakie "Recent History on Ghana" Africa South of The Sahara: (Europa Publication, 2004) pp.479

13 E.M. Debrah, 'Lessons from Ghana's Foreign Policy Since Independence.' Paper presented at a Workshop on 'Ghana's Foreign policy Options' organised by the Legon Centre for International Affairs, University of Ghana. 2002. p. 27

${ }^{14}$ Constitution of the Republic of Ghana: The Directive Principles of State Policy. Chapter 6, Article 40.
} 
peacekeeping functions aim at raising funds for its military due to scarce resources. ${ }^{15}$ Ghana devotes much attention to this type of foreign policy and also considers it to be an internal issue, since regional conflicts could potentially move into its territory and affect internal security ${ }^{16}$ [Emma 2007]. Policies such as participation in regional peacekeeping are considered important to national well-being and the security of the country.

Hebert Howe (1996/97), for instance, argues that, "States often lack adequate military and police forces to control many of these conflicts", and adds that, "Western nations, often hesitate to help police conflicts which do not threaten their own vital interests, and the West and the United Nations have argued that sub-regional organizations and individual states should assume increasing security responsibilities" " [Hebert 1996/97]. Under President Rawlings (1992-2000), Ghana was opposed to meddling in other countries affairs. That was a departure of Dr. Nkrumah `s NonAligned policy. His government believed in the principle of political freedom and social development without interfering in other country`s affairs. In the case of the Cote d'Ivoire coup (1999) for instance, Mr. Rawlings government condemned the act and suspended co operations with Cote d'Ivoire. But in the case of the April 1999 coup in Niger, the Ghanaian government responded differently. Although they condemned the act, Mr. Rawlings did not establish any strong relations with Niger as he did with counties such as Cote d'Ivoire and Nigeria ${ }^{18}$ [Nuamah, 2012]. Although Mr. Rawlings led his ECOWAS colleagues to establish the ECOMOG (Economic Community of West African States Cease-fire Monitoring Group) force to enforce and keep the peace in Liberia. For most of his years, Ghana was less willing to unilaterally condemn military takeovers but nevertheless, he worked through regional institutions to promote reconciliation and a return to constitutional rule.

In spite of the ideological position and leadership style, Ghana `s response to regional crises has not been as readily forthcoming as in others. For example, while Ghana remained silence on the Togolese crises in 2005, it was actively involved in the Ivorian peace process in 2002. Ghana, Nigeria and South Africa were at the forefront of the mediation before an International Working Group (IWG) was established to resolve the crisis ${ }^{19}$ Kwesi, 2007]. Such scenarios certainly contradict it own constitution. As mentioned earlier, the constitution of Ghana is clear in its dealings with other nations. The Directive Principles of State Policy, state its commitment to the principles and objectives upon which ECOWAS policies are based. ${ }^{20}$ The question here is, has Ghana got any clear-cut and pragmatic Foreign Policy in the region, or it`s just being reactionary? Relations with regional neighbours have always been influenced by national interests.

The National Democratic Congress (NDC) and the New Patriotic Party (NPP) pursued the country's foreign policy objectives towards Burkina Faso, Cote d' Ivoire, Togo and Nigeria in a conservative manner. Essentially, the foreign policy behaviour of the two regimes towards the four West African countries among others reflected 'orthodox diplomacy and ideology'; it has been described as politics as usual [Agyeman-Duah and Dadieh 1 994:43].

\footnotetext{
15 Ministry of Foreign Affairs and Regional integration of Ghana View Article: DOI: www.mfa.gov.gh/index.php

16 Emma Birikorang "Ghana`s Regional Security Policy: Cost, benefits and consistency" Kofi Annan International Peacekeeping and Training Centre (KAIPTC) Accra, Ghana. Paper No20. September 2007. p2.

${ }^{17}$ Hebert Howe "Lessons of Liberia and Regional Peacekeeping" International Security, Vol.21 No3, pp.145-179 (The MIT Press, 1996/97)

18 "Evaluation of Ghana's position on democracy challenges abroad" Source: Kwaku Nuamah. View Article: DOI: http://www.ghanaweb.com/GhanaHomePage/soccer/Evaluation-of-Ghana-s-position-on-democracy-challenges$\underline{\text { abroad-30083 }}$

${ }^{19}$ Kwesi Aning “Coping with Crisis, Conflict and Change”: Under Africa: Confronting Complex Threats. p7. February 2007.

${ }^{20}$ Constitution of Ghana: Under the Directive Principles of State Policy. Article 40, Chapter 6.
} 
Sanusi, H., \& Adu-Gyamfi, S. (2017). Ghana's foreign policy: Some regional and national interests. Journal of Human Sciences, 14(1), 598-608. doi:10.14687/jhs.v14i1.4370

\section{Ghana's Involvement in ECOWAS peacemaking:}

Regional peacemaking remain relevant in today's West Africa for a number of reasons: It provides an opportunity for a country to use its scarce resources for other internal development, it is also an opportunity for a country to test its military might. As mentioned earlier, Ghana's involvement in international peacekeeping functions is sometimes also driven more by a desire to raise funds for its military than peace and security concerns. Ghana has benefited from programmes such as the African Crisis Response Initiative (ACRI) and the African Contingency Operations Training and Assistance (ACOTA) from the United States State, and the African Conflict Prevention Pool (ACPP), from the United Kingdom Government ${ }^{21}$ [Birikorang, 2007]. Aside the training assistance it gets from these countries, Volman (2001-2003), adds that, "Law enforcement officers' lifestyles are enhanced and they attain a broader perspective on areas such as human rights, different peacekeeping methods, and the image of Ghana on the international front ${ }^{22}$ [Volman, 2001-2003]. The United Nations (UN), refer peacemaking as "action to bring hostile parties to agreement, essentially through such peaceful means as those foreseen in Chapter VI of the Charter of UN, Pacific Settlement of Disputes"(UNODC 2009: 3).$^{23}$ As Kehinde Bolaji (2011), also contends, peacemaking is the "diplomatic effort intended to move a violent conflict into non violent dialogue, where differences are settled through representative political institutions". The objective of peacemaking is thus to have a lasting solution between parties involved ${ }^{24}$ [Kehinde, 2011].

Although the initial purpose of ECOWAS was to promote economic integration for it members, the organization expanded its mission to deploy military forces into Liberia, Sierra Leone, and Guinea Bissau in 1990, 1997, and 1998, respectively, and then to Côte d'Ivoire and Liberia in 2003. These interventions opened up new avenues for the maintenance of international peace and security. Though Ghana`s participation in the mission had initially been motivated by national interest, it later led to stabilizing peace and security in Liberia. However, some accounts suggest that, Ghana initially encouraged the idea of intervention, with a plan to rescue Ghanaians trapped at the embassy in Monrovia. It is therefore true to state that, Jerry Rawlings ` decision to intervene in Liberia was mainly to rescue Ghanaians whose lives were under serious threat, than on peacemaking concerns. ${ }^{25}$ Rawlings also thought the importance to include the regional leader (Nigeria) to generate international approval. ${ }^{26}$ While the Liberian crisis reveals several common inconsistencies in Ghana 's regional policy, ECOMOG's intervention established several important precedents. On the other hand, Ghana was a member of the ECOWAS Standing Mediation Committee (SMC) which brokered the first ECOWAS peace plan for Liberia that was signed by the three warring factions at the time. A number of peace agreements were brokered by former President Jerry Rawlings who was ECOWAS chairman in $1994 .{ }^{27}$ It has since been involved in preventive diplomacy in Guinea, Guinea Bissau, Togo, Cote d'Ivour, Niger and other flashpoint in the sub-region. Kehinde argues that, "the role of regional organizations and their influence

\footnotetext{
${ }^{21}$ Emma Birikorang "Benefits of Regional Security Involvement" Kofi Annan International Peacekeeping Training Centre, Accra. KAIPTC Paper No. 20, September 2007.

22 Daniel Volman, "US Military Programs in sub-Saharan Africa, 2001-2003". View Article: DOI: www.dvolman@igc.org

${ }^{23}$ UN Office on Drug and Crime (UNODC) 2009. "Transnational Trafficking and the Rule of Law in West Africa: A Threat Assessment. 'Vienna, AT: UNODC.

${ }^{24}$ Kehinde A. Bolaji "adapting traditional principles" The ECOWAS Conflict Prevention Framework. African Conflict \& Peacebuilding Review, issue 1, volume 2 pgs. 183-204. (Indiana University Press, Fall 2011)

${ }^{25}$ Interview with Mr. Victor Gbeho, former Minister of Foreign Affairs and Special Representative of the ECOWAS Chairman in Liberia. June 152006.

${ }^{26}$ Ibid

27 The Akosombo Agreement, 12 September 1994; Accra Acceptance and Accession Agreement, 21 December 1994; Accra Agreement on the Clarification of the Akosombo Agreement 21 December 1994.
} 
Sanusi, H., \& Adu-Gyamfi, S. (2017). Ghana's foreign policy: Some regional and national interests. Journal of Human Sciences, 14(1), 598-608. doi:10.14687/jhs.v14i1.4370

contributed to the decline of the Cold War, and ECOWAS duly took advantage of these changes in international politics" ${ }^{28}$ [Kehinde, 2011].

Regimes after Rawlings also exhibited some level of inconsistencies in their regional policy. In 2003, many expected Ghana to arrest President Taylor of Liberia and send him to the Special Court in Sierra Leone, while attending ECOWAS peace talks in Accra. This is after the Court had ordered for Mr. Taylors arrest for his alleged involvement in the conflict in Sierra Leon. In 2002, this special court was approved by the United Nations, to try those responsible for the crimes committed during the civil war. If the constitution of Ghana clearly adheres to the principles of the UN charter, what then prevented Ghanaian authorities, led by the then President Kufuor, to act on the court`s instructions?. ${ }^{29}$ Although Ghana`s decision on this matter was seen as strategic, it also exposed some level of mistrust and inconsistency in its regional policy, on two vital reasons. First, with respect to the fact that, the crises was regional issue, and as a member of ECOWAS, it only needed to respect the principles and objectives upon which ECOWAS policies are based. Secondly, the primary concern of ECOWAS then was to have a ceasefire in Sierra Leone, since it has encountered some problems in the process of carrying out its objectives, due to political instability and bad governance in some member countries ${ }^{30}$ [Obadan, 2003].

\section{Ramification of Ghana`s Involvement in ECOWAS protocols.}

The West African region is rich in diversity. Its countries differ significantly from one another with regard to history, economic potential, geography, culture, and political systems. While Ghana would form a firm partnership at ECOWAS, the goals of member states cannot be identical in every respect. As Steven (2010), points out, "countries across the region share common characteristics, one of the clearest patterns since the mid-1990s has been significant divergence in economic performance and political change. These differences make it increasingly ill-advised to treat the region as a single entity" ${ }^{31}$ [Steven, 2010]. Ghana's foreign policy attaches great importance to economic diplomacy such as the promotion of trade. Hence, its commitment to ECOWAS protocols which include free movement of goods and services that has created common market for West Africa.

The African continent is a home to many military peace operations, representing approximately 70\% of the UN's worldwide deployments ${ }^{32}$ [Williams 2009: 3 4]. The sub-Saharan region has witnessed most of these instabilities - with its vast natural resources, the West African region remains one of the poorest in the world ${ }^{33}$ [Sesay 2005]. These glaring stats among others, inform Ghana`s commitment to regional peace and security with the hope that, these conflicts doesn't split into its territory. While Ghana takes credit for these attributes: Is Ghana fully committed to its regional policy objectives and principles upon which ECOWAS policies are based. Ghana took strategic stance for being silent, on the coup d'état in neighbouring Togo in the early 2000s, at the time when the Togolese government was accusing Ghana for masterminding the act. ${ }^{34}$ While ECOWAS and its leaders condemned the undemocratic actions in Togo, Ghanaian officials were silent on the matter. It took repeated pressure from ECOWAS and other international organizations to prompt the Ghanaian government to issue a statement on the situation in Togo.

\footnotetext{
${ }^{28}$ Ibid, Kehinde A. Bolaji pgs. 183-204

${ }^{29}$ Interview by Ofeibia Quist-Arcton with President J.A. Kufuor, President of the Republic of Ghana and Chairman of ECOWAS, July 16, 2003. View Article: DOI: www.allafrica.com

30 Obadan, M.I. National Development Planning and Budgeting in Nigeria: Some Pertinent Issues, Lagos: (Broadway Press Ltd, 2003).

31 Steven Radelet: "Emerging Africa: How 17 Countries Are Leading the Way (Center for Global Development, Washington, D.C., 2010)

32 Williams, P. 2009. "Peace Operations in Africa: Seven Challenges, Any Solutions?” Conflict Trends 3: 3-10.

33 Sesay, A. 2005. The West African Scene: A Geopolitical and Socio-Economic Survey and Analysis. Text of a lecture delivered to Course 14 of the National War College. Abuja, Nigeria, September 22.

34 Ghanaian Chronicle "The Furore Over Pres.Kufuor`s Visit To Ghana” (6 Febuary 2001, Accra) View Article: DOI: www.allafrica.com/stoeies/200102070193.html
} 
Sanusi, H., \& Adu-Gyamfi, S. (2017). Ghana's foreign policy: Some regional and national interests. Journal of Human Sciences, 14(1), 598-608. doi:10.14687/jhs.v14i1.4370

This contradicts the case of Cote d'Ivoire, where immediately after the coup in September 2002; Ghana issued a statement condemning the coup and called for the immediate return to constitutional rule ${ }^{35}$.

Historically, the government of Ghana entreated the Togolese government in January 1993 to ensure that an acceptable programme was instituted to return the country to constitutional rule [West Africa, February 8-14, 19 3:207]. The Ghanaian government was of the view that the political and security situation in Togo was not good for democracy as well as peace, and security in the sub region. The influx of refugees from Togo as a result of the crisis there called for the creation of a temporary refugee camp at Klikor in the Volta Region of Ghana. A statement from the government of Ghana hinted that the Ghana Armed Forces had been put on "third degree alert" and was contemplating bringing back home some of its troops serving abroad as a result of the crisis in Togo [West Africa, February 8-14, 19 3:207]. The Togolese government argued that it was prepared to fight till the last man and would not entertain any form of destabilization from the Ghanaian government.

Again on March 1993, the Togolese government accused Ghana of an alleged attack on its main military garrison, which resulted in the death of its Military Chief of Staff, General Mawulikplimi Ameyl and the Deputy Chief of staff, Colonel Kofi Tetteh [West Africa, April 5-11, 1993:545]. The Ghanaian government vehemently denied the accusations and expressed disgust at the Togolese government's paranoia at blaming Ghana for every act of aggression against it, and cautioned the Togolese government to desist from doing that which had the potential to unnecessarily raise tension between the two countries [West Africa, April 5-11, 1993:545].

On $15^{\text {th }}$ October, 2003, the government of Ghana did not miss the opportunity to express its desire to see peace come to Cote'd'lvoire especially when a delegation from the EU was in Ghana on October 15 2003, to confer with President Kuffour on matters of peace and security in the West Africa Sub region [Daily Graphic October 17 2003: 3]. The president called on the UN to assume control of the peace keeping operations in Cote d'lvoire since the involvement of the UN would put the peace process on a sound footing and create the enabling environment for the warring factions in the conflict to work within the framework of the Marcousis and Accra Accords. He added that it was necessary for the UN to help the ECOWAS to deal with sub regional conflicts as soon as practicable. Again, on October 19, 2003, he conferred with Gbagbo at Akosombo as part of diplomatic efforts to bring peace to Cote d'Ivoire. Similarly, he held discussions with prominent lvorian rebel leaders and Alassane Ouattara, previous Ivorian Prime Minister as well as with representatives of the UN and the ECOWAS. Serious impediments to the Lina-Marcoussis Accord during 2004 let to the Accra III Accords in Ghana on July 30, 2004. The Accra III Agreeent reasserted the terms of the Lina- Marcoussis Accord with "specific deadlines and benchmarks for progress" [Daily Graphic October 20 2003: 3.].

Further crisis in Cote d'lvoire called for another meeting in the Nigeria capital, Abuja in November 2004. Ghana was among the six countries that met. Matters got out of hand when Ivorian forces attcked towns in the north of the country killing nine French peace keepers and a US citizen. The French destroyed the Ivorian air force in retaliation. At the end of their one-day summit, the leaders called on the international community to place an arms embargo on Cote d'lvoire without delay. This was duly done on November 152004 [Daily Graphic November, 17 2004: 5].

However, in 2010-2011, Ghanaian government chose to remain silent on the Cote d'Ivoire crises. This is after several countries and international organizations such as the UN, AU and ECOWAS have recognized the opposition leader as the legitimate president of the country ${ }^{36}$ [Aning

\footnotetext{
35 "Evaluation of Ghana's position on democracy challenges abroad" Source: Kwaku Nuamah. View Article: DOI: http://www.ghanaweb.com/GhanaHomePage/soccer/Evaluation-of-Ghana-s-position-on-democracy-challengesabroad-30083

${ }^{36}$ Kwesi Aning \& Samuel Atuobi “The Challenges of The Côte d'Ivoire Crisis For West Africa: Exploring Options For
} 
Sanusi, H., \& Adu-Gyamfi, S. (2017). Ghana's foreign policy: Some regional and national interests. Journal of Human Sciences, 14(1), 598-608. doi:10.14687/jhs.v14i1.4370

\& Atuobi, 2011]. Noting the fact that, over one million Ghanaians live in La Côte d'Ivoire. Ghana initially announced that, it will not send any troops into the country, on grounds that its men are already in peacekeeping operations elsewhere. ${ }^{37}$

In responding to the crisis at a press briefing, President Mills did not consider what Ghana `s first President said, "The independence of Ghana is meaningless unless it is linked up to the total libration of Africa" -he rather surprised the media with a local expression "Dzi wo fie asem" (Mind your own business), stating that, Ghana cannot choose a President for Côte d'Ivoire. This is one proclamation that shocked the large mass of stakeholders. While this clearly contradicts the Non-Aligned policies, which fosters cooperation among Africans through regional integration such as ECOWAS, it can also be seen as disappointment and betrayal to the ECOWAS. Whichever way we look at it, one would have thought that Prof. Mills would have been more vocal on issues affecting the African continent, just as Nkrumah did. This is the President who saw Nkrumah as a role model. For instance, in his first year in office, President Atta Mills ordered the birth date of Dr. Nkrumah as a national holiday. Could regime in power be the reason for these possible inconsistencies? How does the founding ideals of non-aligned policy which objectives include, democratization of international relations, reconcile with such acts? Or Ghana's foreign policy which is committed to maintaining friendly relations and co-operations with all countries that desire such co-operations?

The killing of 44 Ghanaian nationals in the Gambia in 2005 saw deterioration in GhanaGambia relations, after Ghana accused Yahya Jammeh of Gambia and his military for the killings. ${ }^{38}$ The then minority spokesperson for foreign affairs John Mahama, (who served as President of Ghana from 2012-2016), urged all Ghanaians not to welcome Mr. Jammeh, who was scheduled for an African Union summit in Accra. His call eventually made Mr. Jammeh cancel his trip to the AU summit. ${ }^{39}$ With its "role model" status and influential actor at ECOWAS, one expected Ghana to act in a way that does not affect their diplomatic relations, since both are members of this organization. While this issue has not been resolved, Mr. Mahama`s recent visit to the Gambia again raises concern, over whether Ghana has got a clear cut foreign policy towards the subregion. ${ }^{40}$

Finally, Nigeria`s security challenges which started in 2009, saw the formation of a Multinational Joint Force (MNJTF): ${ }^{41}$ — with Nigeria, Cameroon, Chad and Benin to fight Boko Haram, that has killed thousands in northeast Nigeria. Again, Ghana`s exclusion from this group is still a mystery since the Islamist group are increasingly threatening neighbouring countries. Republic of Benin, who has not been affected by this terrorist acts, for instance, saw the importance of this joint force. Nigeria`s instability is adversely a blow for Ghana. Aning (2007) believes that "Migratory flows of Nigerians seeking zones of peace would almost certainly ruin the economies of a country such as Ghana, and states much further afield". But more critically, such scenarios could also lead to the loss of a key continental stabilization anchor - a sub-regional leader ${ }^{42}$ [Aning, 2007]. This clearly shows that, where strategic economic and personal interests are as stake, Ghanaian leaders have chosen cooperation and friendship over condemnations. ${ }^{43}$

\footnotetext{
A Negotiated Settlement” (Policy Brief, 4 January 2011) p.3

${ }^{37}$ Ibid

${ }^{38}$ Report: "Gambian President Ordered Killing of Ghanaians" - Reveals Top Govt Official. View Article: DOI: http://www.ghanaweb.com/GhanaHomePage/diaspora/Gambian-President-Ordered-Killing-of-Ghanaians -RevealsTop-Govt-Official-110360

${ }^{39}$ Yahya Jammeh excuses AU Summit View Article: DOI: http://www.modernghana.com/newsthread1/138597/4/

${ }^{40}$ President of Ghana, John Maham visited Gambia in 2015. View Article: DOI: www.newsghana.com.gh

${ }^{41}$ A Regional Multinational Joint Task Force to Combat Boko Haram. View Article: DOI: http://pncp.net/news/regional-multinational-joint-task-force-combat-boko-haram

42 Emmanuel Kwesi Aning “Africa: Confronting Complex Threats” p11.(International Peace Academy, 2007)

${ }^{43}$ Democracy Coalition Project, Defending Democracy: A Global Survey of Foreign Policy Trends 1992-2002. View Article: DOI: www.demcoalition.org
} 


\section{Conclusion and Recommendations:}

The year 1992, was a period that saw the introduction of constitution to be used in governance, and also marked the start of democracy in Ghana. Hence, the only document that defines and guides courses of action in Ghana's foreign policy is the 1992 Constitution. These include, strengthening of the United Nations, democratization of international relations, socioeconomic development and the restructuring of the international economic system, as well as international cooperation on an equal footing, maintaining friendly relations and co-operation with all countries that desire such co-operation on the basis of mutual respect and adherence to the principles and charter obligations of international organisations to which Ghana belongs. ${ }^{44}$ In view of the activities and roles it plays in ECOWAS, there is the need for Ghana to have a comprehensive defence and national security policy. This will guide the decisions and actions of future governments in their interactions within the region. This leads to the hypothesis that, lack of a well-defined and articulated defence policy document has somewhat resulted in inconsistencies in responding to crisis such as those in Niger, Cote d'Ivoire and the Gambia. These are sometimes difficult for ECOWAS, to predict what to expect from its member states in terms of commitment to agreed protocols and decisions.

As a developing country, Ghana should pursue foreign policy which favours all actors of the international community. This is to avoid friction between member states, especially its immediate neighbours and the wider world. Also, efforts should be made to strengthen Ghana `s commitment to international organizations, namely Economic Community of West African States (ECOWAS), African Union (AU), United Nations Organisation (UNO), Non-Aligned-Movement, and the Commonwealth of Nations. Finally, measures should be taken to promote economic growth. Although the Non-Aligned policy has helped Ghana to strengthen its international cooperation on an equal footing, the discussion revealed that, part of Ghana`s foreign policy has been influenced by the need for external economic assistance which has influenced most decisions taken in the past. To stem this problem, Ghana 's economy should be diversified from over dependent on external sources. The regional bloc remains important for Ghana; -its economic and political dispensations. If Ghana is to play a significant role in ECOWAS, it must vigorously involve itself in the move toward an improved policy framework in the sub-region.

\section{List of Acronyms}

$\begin{array}{ll}\text { ECOWAS } & \text { Economic Community of West African States } \\ \text { FP } & \text { Foreign Policy } \\ \text { AL } & \text { Arab League } \\ \text { AU } & \text { African Union } \\ \text { EU } & \text { European Union } \\ \text { ECOMOG } & \text { Economic Community of West African States Monitoring Group } \\ \text { UN } & \text { United Nations } \\ \text { WAS } & \text { West African States } \\ \text { NAM } & \text { Non- Alignment Movement } \\ \text { PNDC } & \text { Provisional National Defence Council } \\ \text { UNO } & \text { United Nations Organisation } \\ \text { UK } & \text { United Kingdom } \\ \text { MNJTF } & \text { Multinational Joint Force } \\ \text { ACPP } & \text { African Conflict Prevention Pool } \\ \text { ACOTA } & \text { African Contingency Operations Training and Assistance }\end{array}$

${ }^{44} 1992$ Constitution of the Republic of Ghana. See also Hon. Hackman Owusu-Agyeman, 'Ghana's Foreign Policy under the Kufuor Administration', Paper presented at a Workshop on 'Ghana's Foreign policy Options' organized by the Legon Centre for International Affairs, University of Ghana. 2002. 
Sanusi, H., \& Adu-Gyamfi, S. (2017). Ghana's foreign policy: Some regional and national interests. Journal of Human Sciences, 14(1), 598-608. doi:10.14687/jhs.v14i1.4370

ACRI

WA

NPP

IWG

OAU

NDC
African Crisis Response Initiative

West Africa

New Patriotic Party

International Working Group

Organisation of African Unity

National Democratic Congress

\section{References}

Afua Boatemaa Yakohene "Overview of Ghana and Regional Intergration: Past, Present and Future (Friendrich-Ebert-Stiftung, Ghana, 2009).

Daniel Volman, "US Military Programs in sub-Saharan Africa, 2001-2003”. www.dvolman@igc.org (Accessed 06/04/2008)

Democracy Coalition Project, Defending Democracy: A Global Survey of Foreign Policy Trends 1992-2002. www.demcoalition.org. (Accessed on 29/06/2006)

E. M. Debrah, 'Lessons from Ghana's Foreign Policy Since Independence.' Paper presented at a Workshop on 'Ghana's Foreign policy Options' organised by the Legon Centre for International Affairs, University of Ghana. 2002. p. 27

Emma Birikorang "Ghana`s Regional Security Policy: Cost, benefits and consistency" Kofi Annan International Peacekeeping and Training Centre (KAIPTC) Accra, Ghana. Paper No20. September 2007. p2.

Emmanuel Kwesi Aning "Coping with Crisis, Conflict and Change": Under Africa: Confronting Complex Threats. p7. February 2007.

Evans S.c. Osabuohien "Trade Openness and Economic Performance of ECOWAS MembersReflections From Ghana And Nigeria". African Journal of Business and Economic Research (AJBER) Vol.2 Nos. 2\&3, pp57-73. (Covenant University Ota, Nigeria 2007)

F. S. Northedge (1918-1985), was a British Professor of International Relations at the London School of Economics.

Ghanaian Chronicle "The Furore Over Pres. Kufuor`s Visit To Togo" (6 Febuary 2001, Accra) www.allafrica.com/stoeies/200102070193.html (accessed 27/08/2016)

G. R. Bluwey, "Understanding International Relations” (Accra: Yamens Press Limited, 2003) pp4445.

Hackman Owusu-Agyeman, 'Ghana's Foreign Policy under the Kufuor Administration', Paper presented at a Workshop on 'Ghana's Foreign policy Options' organized by the Legon Centre for International Affairs, University of Ghana. 2002.

Hebert Howe "Lessons of Liberia and Regional Peacekeeping" International Security, Vol.21 No3, pp.145-179 (The MIT Press, 1996/97)

Interview by Ofeibia Quist-Arcton with President J.A. Kufuor, President of the Republic of Ghana and Chairman of ECOWAS, July 16, 2003. www.allafrica.com. (Accessed on 7 July 2006)

Interview with Mr. Victor Gbeho, former Minister of Foreign Affairs and Special Representative of the ECOWAS Chairman in Liberia. June 152006.

Kwaku Nuamah "Evaluation of Ghana's position on democracy challenges abroad" Article available: http://www.ghanaweb.com/GhanaHomePage/soccer/Evaluation-of-Ghana-sposition-on-democracy-challenges-abroad-30083 (accessed, 01/12/2002)

Kwame, Boafo- Arthur, "Trends in Ghana" s Foreign Policy after Nkrumah" in Hansen, E. and Ninsin, K. A. (eds.),

Kehinde A. Bolaji “adapting traditional principles" African Conflict \& Peacebuilding Review. issue 1, volume 2 pgs. 183-204 (Indiana University Press-2011)

Kwesi Aning \& Samuel Atuobi “The Challenges of The Côte d'Ivoire Crisis For West Africa: Exploring Options For A Negotiated Settlement” (Policy Brief, 4 January 2011) p.3

Mark Webber \& Michael Smith "Foreign Policy in a Transformed World" (Loughborough University, 2002) 

Sciences, 14(1), 598-608. doi:10.14687/jhs.v14i1.4370

T.C.McCakie "Recent History on Ghana" Africa South of The Sahara: (Europa Publication, 2004) pp.479

Ministry of Foreign Affairs and Regional integration of Ghana: www.mfa.gov.gh/index.php (accessed, 09/01/2016)

Obadan, M. I. National Development Planning and Budgeting in Nigeria: Some Pertinent Issues, Lagos: (Broadway Press Ltd, 2003).

President of Ghana, John Maham visit to Gambia in 2015: www.newsghana.com.gh (Accessed 27/08/2016)

Report: "Gambian President Ordered Killing of Ghanaians" - Reveals Top Govt Official http://www.ghanaweb.com/GhanaHomePage/diaspora/Gambian-President-OrderedKilling-of-Ghanaians -Reveals-Top-Govt-Official-110360 (Accessed 10/09/2006)

Report on Regional Multinational Joint Task Force to Combat Boko Haram. http://pncp.net/news/regional-multinational-joint-task-force-combat-boko-haram (Accessed 20/08/2016)

Rodrigo Tavares: African Studies Review, Volume 54. Nuvember 2, September 2011, pp.145-176 (Cambridge University Press, 2011)

Sesay, A. 2005. The West African Scene: A Geopolitical and Socio-Economic Survey and Analysis. Text of a lecture delivered to Course 14 of the National War College. Abuja, Nigeria, September 22.

Steven Radelet: "Emerging Africa: How 17 Countries Are Leading the Way (Center for Global Development, Washington, D.C., 2010)

The Akosombo Agreement, 12 September 1994 Accra, Acceptance and Accession Agreement, 21 December 1994.

The Formation of ECOWAS treaty: Agreement signed by member states. Lagos 1975.

T.C. McCakie "Recent History on Ghana" Africa South of The Sahara: (Europa Publication, 2004) pp.479

The Constitution of the Republic of Ghana: under the Directive Principles of State Policy. Chapter 6, Article 40.

UN Office on Drug and Crime (UNODC) 2009. "Transnational Trafficking and the Rule of Law in West Africa: A Threat Assessment.'Vienna, AT: UNODC.

Williams, P. 2009. "Peace Operations in Africa: Seven Challenges, Any Solutions?" Conflict Trends 3: 3-10.

William Willace, "Foreign Policy and National Identity in the United Kingdom" (Royal Institute of International Affairs, January 1991) Vol. 64, No 1. pp. 65-80. 